\title{
Medical problems in the honeymoon in newly married couples: An overview
}

\author{
Raeef Ahmad Qutob, Mutlak Abdullah Al Malky, Khalid Mohammad Al Aboud \\ Department of Internal Medicine, General surgeryand Public Health, King Faisal Hospital, Makkah, Saudi Arabia
}

Email address:

amoa65@hotmail.com (K. M. Al Aboud)

To cite this article:

Raeef Ahmad Qutob, Mutlak Abdullah Al Malky, Khalid Mohammad Al Aboud. Medical Problems in the Honeymoon in Newly Married Couples: An Overview. Clinical Medicine Research. Vol. 3, No. 5, 2014, pp. 159-161. doi: 10.11648/j.cmr.20140305.20

\begin{abstract}
This is an overview on the medical problems, which might occur in the honeymoon period. The medical problems include several uncommon conditions. The most discussed ones in the medical literature are honeymoon cystitis and vaginismus .Future couples are also prone to skin diseases from overuse of cosmetics before wedding. A particular attention, in our paper, is given to the potential sexual injuries which may occur to the couples in this period together with a discussion on how to decrease their occurrence.
\end{abstract}

Keywords: Diseases, Honeymoon, Marriage, Sex

\section{Introduction}

A honeymoon is a holiday taken by newlyweds to celebrate their marriage. It is known tradition in many parts of the world. Honeymoons are often celebrated in destinations considered exotic and/or romantic.

Newly married couples faces special psychological and social circumstances. Couples in this period are prone to any medical problems which may occur in any time during their life periods. Moreover, a future husband or wife with systemic diseases such as diabetes may experience difficulty in controlling their diseases at this period due to psychological and physical stresses.

However, our aim was to review the conditions reported in medical literature linked in particular to the honeymoon period. We performed a search in the PubMed; a wellknown scientific database with appropriate search words. The results we obtained are summarized table. $1^{1-18}$.

It is of paramount for health care providers to know about the potential medical problems that may face honeymooners, in order to provide them with the proper and the needed education and advices.

\section{A Perspective from Saudi Arabia}

The authors of this paper think that there are hidden cases of sexual injuries to the newly married girl's .This problem are not projected well in our country due to the conservative nature of our society. Sexual injuries in the early marital life may have deleterious physical and psychological impacts on both partners.

The Saudi Royal Cabinet issued the Saudi Royal Decree on Sep 2003, establishing the pre-marital examination as a health preventive measure for all Saudis, and requesting the 2 prospective partners (male and female) to carry out a premarital examination and present a certificate of pre-marital examination before the wedding ${ }^{18}$.

This program was established primarily to decrease the burden of hereditary blood disorders. However, the program expanded to include testing the future partners for viral diseases like hepatitis and HIV.

\section{Conclusion}

We believe that the integration of health education to the partners on the proper sexual practice shall make the premarital examination program more useful and could prevent sexual injuries in the start of marital life.

The education program may utilize the Islamic texts as all Saudi are Muslims.

In the holy book of Islam "Quran", it is written "It is made lawful for you, in the nights of fasts, to have sex with your women. They are apparel for you, and you are apparel for them. Allah knows that you have been betraying yourselves, so He relented towards you and pardoned you. So now you can have sexual intimacy with them and seek 
what Allah has destined for you". [al-Baqarah 2:187].

A garment brings satisfaction, comfort, protection and warmness! These are the things a husband must strive to give his wife during intercourse!

Islam stresses that the act of sex should be to please both partners. Prophet Mohammad peace be upon him advice for foreplay, which is very important to make the female physically and psychologically ready for the act of sex and hence provide a good measure to protect against sexual injuries.

Foreplay between the spouses before actually engaging into sexual intercourse is immensely important (especially for the wife) and a vital ingredient for a happy and prosperous marriage. That is why the prophet forbade sexual intercourse without foreplay, to guarantee and to protect the sexual pleasures and rights of the wife in bed ${ }^{19}$.

Table $\mathbf{1}^{1-17}$. Selected problems reported in medical literature linked to honeymoon period:

\begin{tabular}{|c|c|}
\hline The medical problems & Remarks \\
\hline Honeymoon asthma ${ }^{1}$. & $\begin{array}{l}\text { This is a suggested term for a rare but known entity-asthma provoked by sexual activity at a level of physiological } \\
\text { stress below that required to trigger exercise-induced asthma. }\end{array}$ \\
\hline Honeymoon cystitis ${ }^{2}$. & $\begin{array}{l}\text { Also known as "honeymoon disease". The symptoms are the same as with cystitis triggered by something other } \\
\text { than sex. The disease predominantly affect women, because their urethra is much shorter than the male urethra. It } \\
\text { can be prevented by drinking plenty of water, going to the bathroom as often as you need to, and peeing right after } \\
\text { sex. } \\
\text { Management includes proper use of antibiotics. Urethroplasty should be considered in suitable cases when } \\
\text { conservative methods of treatment have failed, and especially in patients whose urethral meatus lies in an } \\
\text { intravaginal position. }\end{array}$ \\
\hline Honeymoon impotence ${ }^{3-5}$. & $\begin{array}{l}\text { It is a failure to be successfully involved in sexual intercourse at the beginning of marriage, particularly in the first } \\
\text { few nights. It can be due to psychogenic or vasculogenic erectile dysfunction . The evaluation of the penile } \\
\text { vascular system in patients with honeymoon impotence is important. } \\
\text { Sildenafil, Tadalafil, intracavernous injection therapy, and psychosexual therapy were used effectively in the } \\
\text { treatment of honeymoon impotence. }\end{array}$ \\
\hline Honeymoon meningitis ${ }^{6}$. & $\begin{array}{l}\text { This is a term proposed for a rare case of S. agalactiae meningitis, reported in a previously healthy young woman } \\
\text { following sexual intercourse for the first time. The vaginal flora was the verified source of infection. }\end{array}$ \\
\hline $\begin{array}{l}\text { Honeymoon Malaria and other } \\
\text { tropical diseases }{ }^{7,8} \text {. }\end{array}$ & $\begin{array}{l}\text { Travelers in general including those going for honeymoon are prone to get any endemic infectious diseases from } \\
\text { the areas they are visiting. Proper medical advices and vaccinations should be sought from travel clinic before } \\
\text { planning to travel. As an example vaccines for hepatitis A and diphtheriatetanus are recommended for all } \\
\text { developing countries while Polio is still indicated for Asia and Africa. }\end{array}$ \\
\hline Honeymoon psychosis ${ }^{9}$. & $\begin{array}{l}\text { This term is suggested for a type of psychosis observed in Japanese honeymooners in Hawaii. The tradition of } \\
\text { arranged marriage and other cultural factors were claimed to be a precipitating factor. }\end{array}$ \\
\hline Honeymoon rhinitis ${ }^{10}$. & $\begin{array}{l}\text { It refers to a nasal congestion which occurs during sexual intercourse .It appears to be genetically determined, and } \\
\text { caused by the presence in the nose of erectile tissue which may become engorged during sexual arousal. In the } \\
\text { same context, it is also important to note, that nasal congestion is a reported side effect of Viagra use. }\end{array}$ \\
\hline Sexual injuries ${ }^{11-15}$. & $\begin{array}{l}\text { Sexual injury occurred in women as vaginal laceration and in man as penile fracture. The commonest site of } \\
\text { injury for the females was the posterior vaginal fornix. It is postulated that these vulnerable sites of vaginal } \\
\text { laceration may be due to the dextro-rotation characteristics of the uterus and the distensibility of the vagina in this } \\
\text { area. A It is caused by the use aggressive sexual technique by the males and disproportionate genital size between } \\
\text { the partners. Female genital mutilation (FGM) which is not uncommon in developing countries may be a factor for } \\
\text { this problem and other sexual dysfunction such as dyspareunia. }\end{array}$ \\
\hline Skin disaeses ${ }^{16}$. & $\begin{array}{l}\text { Males and females planning for wedding are interested to look good and hence they are susceptible to various skin } \\
\text { diseases like contact dermatitis from cosmetics. } \\
\text { Existing infectious genital skin diseases in one partner may be transmitted to his or her partner. }\end{array}$ \\
\hline Vaginismus (vaginism) ${ }^{17}$ & $\begin{array}{l}\text { It is the physical or psychological condition that affects a woman's ability to engage in any form of vaginal } \\
\text { penetration, including sexual intercourse .It is an overlooked topic in conservative societies. Conventional therapy } \\
\text { proved effective in mild and moderate cases, while botulinum toxin has a more rapid effect and was thus more } \\
\text { effective in severe cases8. }\end{array}$ \\
\hline
\end{tabular}

\section{References}

[1] Senthilkumaran S, Pant S, Menezes RG, Balamurgan N, Thirumalaikolundusubramanian P, Bartter T. Honeymoon asthma. Am J Med Sci 2013; 345(5):405-6.

[2] Smith PJ, Roberts JB, Ball AJ. "Honeymoon" cystitis: a simple surgical cure. Br J Urol 1982; 54(6):708-10.
[3] Shamloul R. Management of honeymoon impotence. J Sex Med 2006; 3(2):361-6.

[4] Usta MF, Erdoğru T, Tefekli A, Köksal T, Yücel B, Kadioğlu A. Honeymoon impotence: psychogenic or organic in origin? Urology 2001; 57(4):758-62.

[5] Ghanem H, El-Dakhly M, Shamloul R. Alternate-day tadalafil in the management of honeymoon impotence. J Sex Med 2008; 5(6):1451-4. 
[6] Agouridakis P, Ioannidou E, Dalezios M, Panagopoulou V, Drandakis P. "Honeymoon" meningitis. Emerg Med J 2005; 22(11):803-4.

[7] Schmid ML, Green ST, Read RC. Honeymoon malaria and "herbal" therapy: A case report. J Travel Med 1999; 6(4):261.

[8] Stürchler MP, Steffen R. [Vaccinations for overseas travelers--new evidence and recommendations]. TherUmsch $2001 ; 58(6): 362-6$

[9] Langen D, Streltzer J, Kai M. "Honeymoon psychosis" in Japanese tourists to Hawaii. Cult Divers Ment Health1997; $3(3): 171-4$

[10] Monteseirin J, Camacho MJ, Bonilla I, Sánchez-Hernández C, Hernández M, Conde J. Honeymoon rhinitis. Allergy 2001; 56(4):353-4.

[11] Hoffman RJ, Ganti S.Vaginal laceration and perforation resulting from first coitus. PediatrEmerg Care 2001; 17(2):113-4.

[12] Savaş A, Efesoy O, Cayan F, Cayan S. [Sexual injuries during consensual sexual activity]. Ulus Travma Acil Cerrah iDerg 2012 Nov; 18(6):519-23.
[13] Jeng CJ, Wang LR. Vaginal laceration and hemorrhagic shock during consensual sexual intercourse. J Sex Marital Ther 2007; 33(3):249-53.

[14] Uğurel V, Özer DP, Varol F. A rare case of rectovaginal fistula following consensual vaginal intercourse. J Sex Med 2014; 11(5):1345-8.

[15] Rouzi AA, Sahly N, Alhachim E, Abduljabbar H. Type I Female Genital Mutilation: A Cause of Completely Closed Vagina. J Sex Med2014 May 30.

[16] Al Aboud A, Kirti N, Ramesh V.Wedding ceremony and skin diseases; a need for vigilance!J Pak Assoc of Dermatol 2011; 21: 109-111.

[17] Fageeh WM. Different treatment modalities for refractory vaginismus in western Saudi Arabia. J Sex Med 2011; 8(6):1735-9.

[18] El-Hazmi MA. Pre-marital examination as a method of prevention from blood genetic disorders. Community views. Saudi Med J 2006; 27(9):1291-5.

[19] AleemDomun N..How to make love to your wife in Islam!. Available online from ;http://www.mydeenislam.com/howto-make-love-to-your-wife-in-islam. (accessed 1 Sep 2014) 